\title{
PLATELET-RICH FIBRIN AS A POSSIBLE AUTOGENOUS TRANSPORT MEDIUM FOR AVULSED TEETH: AN IN VITRO STUDY
}

\author{
Talat Mohamed Beltagy*, Elsayed Mohamed Deraz** and Ahmed Abdelaziz Mohamed Essa***
}

\begin{abstract}
Objectives: Replantation of avulsed tooth depends on the viability of periodontal ligament cells. The aim of this study was to evaluate the survival of periodontal ligament cells (PDL) when placed in platelet-rich fibrin (PRF) transport media after an extra-oral dry time of 40 minutes.

Method: Forty human mandibular first premolar teeth with healthy periodontium and closed apices, previously planned for orthodontic extraction, were selected. The teeth were randomly divided into study group, PRF and control group, Hank's balanced salt solution (HBSS) as a reference medium. In both groups, the teeth were stored dry for 40 minutes, followed by 30 minutes immersion in the study and control media.
\end{abstract}

Results: There is a statistically significant increase in the number of viable PDL cells in PRF group as compared to reference medium group.

Conclusion: PRF demonstrated higher number of viable PDL cells and hence could be a suitable transport medium for avulsed teeth.

KEYWORDS: Platelet-rich fibrin, avulsed teeth

\section{INTRODUCTION}

Loss of teeth due to dento-alveolar trauma affects great part of the population especially the children; leading to significant negative functional, esthetic, and psychological problems on children. ${ }^{(1)}$ Tooth avulsion is considered as the severe form of all traumatic dental injuries and it is characterized by complete displacement of the tooth out of its socket ${ }^{(2)}$. The incidence of avulsion reaches about $16 \%$ of all traumatic injuries affecting permanent teeth ${ }^{(3)}$. The most common age affected by injuries to permanent teeth occur between 7 and 10 years old secondary to falls, traffic accidents, violence, and sports practices ${ }^{(4)}$.

Replantation is widely accepted as an effective solution for avulsed teeth but the prognosis of avulsed tooth cannot be predicted and depends on various factors such as extra-oral dry time, the storage medium, state of pulp vitality and periodontal tissues, root development and the period of splinting ${ }^{(5)}$.

\footnotetext{
* Assistant Professor of Pedodontics, Faculty of Dentistry, Kafr El-Sheikh University, Egypt. ** Assistant Professor of Oral Pathology, Oral Pathology Department, Tanta University, Egypt. *** Lecturer of Oral Pathology, Oral Pathology Department, Tanta University, Egypt.
} 
Different techniques were used for preserving the avulsed teeth until replantation. Immediate replantation of the avulsed tooth into the socket is the appropriate biological way, but this technique is not always possible ${ }^{(6)}$ due to the extra alveolar time interval before the patient arrives to the dentist. This leads to root surface dehydration, and increasing the risk of loss the vitality of the periodontal ligament (PDL) cells ${ }^{(7)}$. If the replantation is delayed more than 5 minutes; the avulsed tooth should be stored in a physiologic transport medium to maintain the vitality of the PDL, and pulpal cells as well as preservation of tissue viability, physiologic $\mathrm{pH}$ and osmolality similar to the surrounding tissues ${ }^{(8)}$.

Numerous media have been used for storage of avulsed teeth. Tap water has been shown to be almost as harmful to the periodontal ligament fibroblasts (PDLF) as dry storage ${ }^{(9)}$. Saliva and physiologic saline have been recommended for many years as storage media, but only for a short time and may result in PDLF death as saliva is very hypotonic and harbor different bacteria ${ }^{(10,11)}$. Other storage media as milk, Save-A-Tooth system and Via Span are also used but not readily available in all countries ${ }^{(12)}$. Egg white, powdered milk, Gatorade and Propolis have been recently studied and tested ${ }^{(13,14)}$.

If the extra-oral dry time of avulsed tooth is more than 20 minutes ${ }^{(8,15,16)}$, there is a considerable risk for ankylosis. However, the risk of pulp necrosis, root resorption, and ankylosis significantly increases with an extra-oral dry time of 60 minutes ${ }^{(17,18)}$ and the tissue regeneration is highly indicated.

Hank's balanced salt solution (HBSS) is the gold standard storage media with ideal $\mathrm{pH}$ of 7.2 and osmolality of $270-290 \mathrm{osmo} / \mathrm{kg}$. It contains essential metabolites that necessary to preserve the vitality of PDL cells. It has been widely used as a reference media in studies on tooth avulsion ${ }^{(19,20)}$.

Platelet rich fibrin (PRF) is a second generation platelet concentrate. It is an autologous platelet concentrate and leukocyte. Alpha granules that are released from the activated fibrin membrane enriched with platelets and growth factors play a crucial role in soft and hard tissue regeneration. Also, the enmeshed cytokine polypeptides in concentrate influence the extracellular matrix which allows migration, division and phenotypic change of endothelial cells, leading to angiogenesis ${ }^{(21-23)}$. This autologous scaffold gives the highly needed biochemical mediators for enhancing the regeneration of the periodontium ${ }^{(24)}$.

Although plenty of studies have been used for treatment of avulsed teeth, our in vitro study introduced the survival of periodontal ligament cells of avulsed teeth through the use of PRF as an autologous biologic medium compared with the gold slandered rejuvenating medium HBSS.

\section{MATERIALS AND METHODS}

Forty human first premolar teeth with healthy periodontium and closed apices, previously planned for orthodontic extraction (Fig. 1A), were selected. Atraumatic technique was performed for the extractions. Following extractions, the teeth were held with forceps by the crown, and the coronal 3 $\mathrm{mm}$ of PDL was scraped with a curette and rinsed with distilled water to remove cells that may have been severed during extraction. The teeth were randomly divided into two groups $(\mathrm{n}=20)$.

Group 1 (study group): Platelet-rich fibrin (PRF) (Fig. 1B).

Group 2 (control group): Hank's balanced salt solution (HBSS) (Fig. 2A) as a reference medium.

In both groups, the teeth were stored dry for 40 minutes, followed by a 30 minutes immersion in the study and reference media (Fig. 1C; arrow and arrow head respectively). Written consent was obtained from all volunteers. The experimental protocol for analyzing surgical materials was reviewed and approved by the Ethical Board of Faculty of Dentistry, Tanta University. 


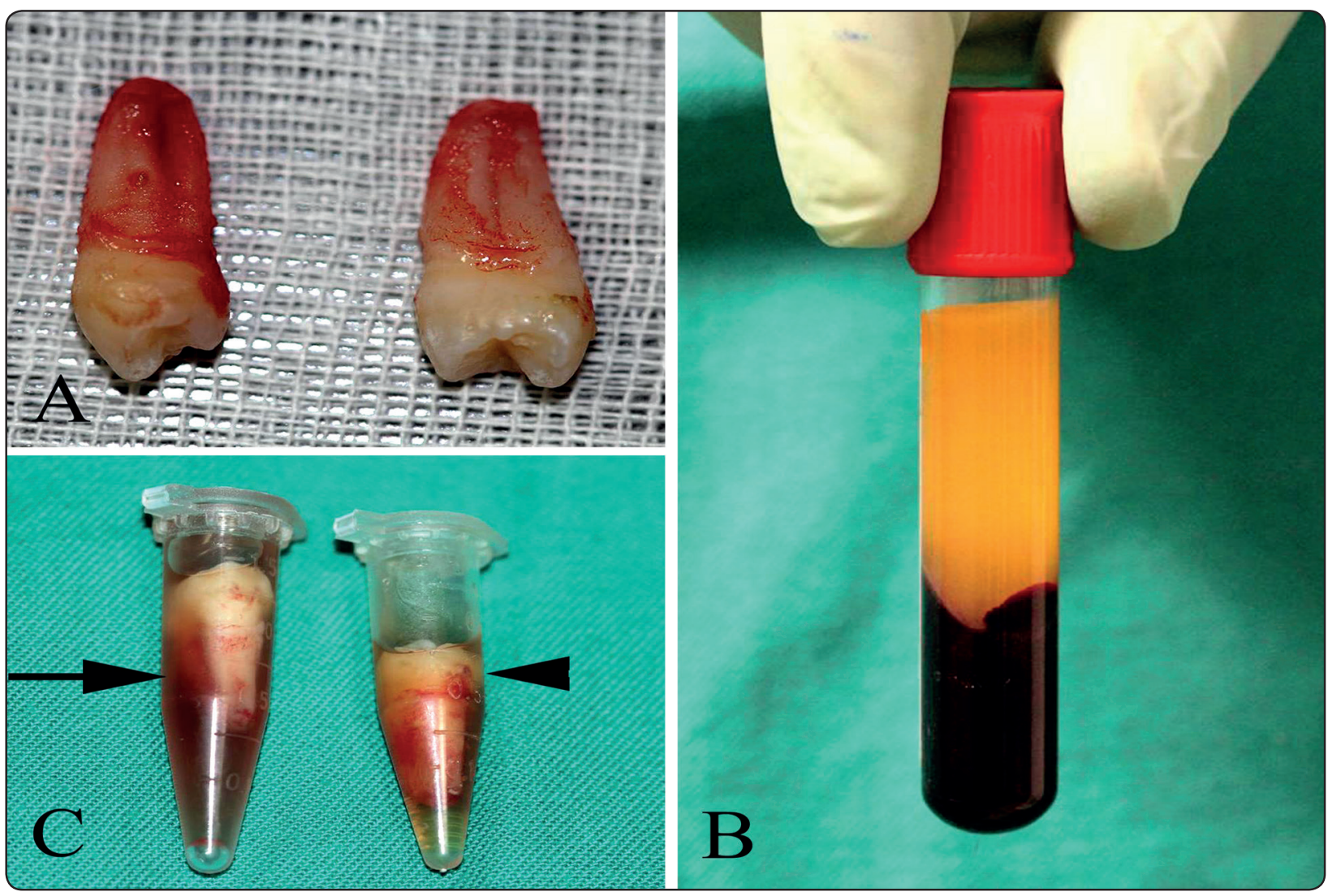

Fig (1) Extracted non-carious mature premolar teeth (A); preparation of platelet rich fibrin (B); Extracted teeth storage in study; (arrow) and reference media; (arrow head) (C).

Prior to teeth extraction, $5 \mathrm{ml}$ of venous blood was collected from 20 healthy orthodontic patients from whom 40 teeth had been harvested for the study. PRF was obtained by centrifugation of collected blood at $705.6 \mathrm{~g}$ for 12 minutes with a PC02 table centrifuge (REMI, Mumbai, India).

Each tooth in both groups was treated separately and incubated for 30 minutes in $15-\mathrm{ml}$ falcon tubes with 2.4-mg ml-1 solution of Dispase grade II (Fig. 2B) in phosphate-buffered saline (PBS) (Fig. 2C). The specimens were centrifuged for $8 \mathrm{~min}$ at 5000 rpm, and the supernatant was then removed with sterile micropipette; the cells were labeled with $0.4 \%$ trypan blue (Fig. 2D) (Lonza).

Trypan Blue stains non-viable cells blue and viable cells appear color-less or pink. Following staining, the cells were observed with the help of hemocytometer with an optical microscope

\section{Determination of the number of cells (total and viable):}

The cells were viewed under a microscope at $\times 100$ magnification. The number of cells (total and non-viable) was determined by counting the cells overlying a $4 \times 1 \mathrm{~mm}^{2}$ area of the counting chamber.

The viable cell percentage was calculated as:

[(Total cells - Stained cells $) /$ Total Cells $] \times 100$

The number of total cells, nonviable (stained cells) and viable cells from both transport and reference media were collected, tabulated and statistically analyzed. A $P$-value $<0.05$ was required for assessing the significance. 


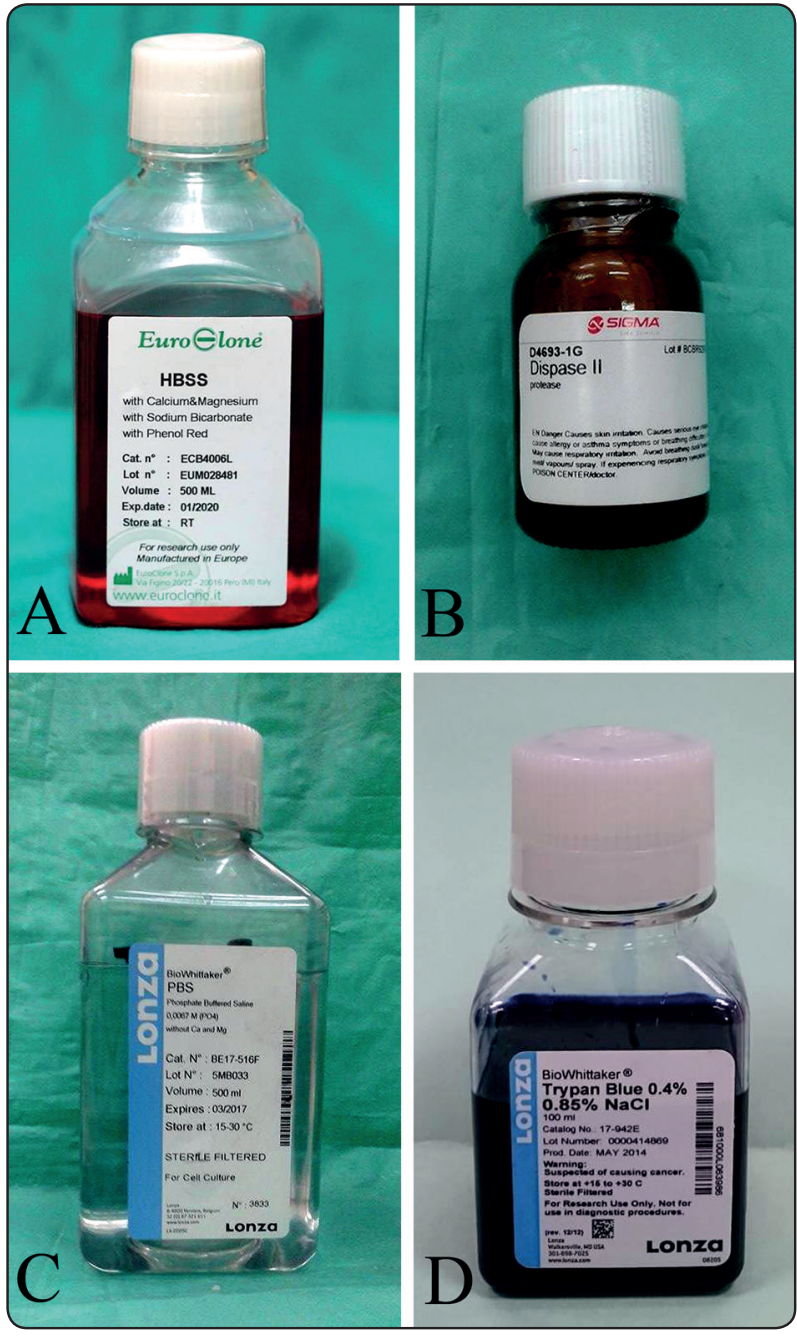

Fig. (2) Materials used in this study; Dispase grade II (A) Hank's balanced salt solution (B); phosphate-buffered saline (C); Trypan blue (D).

\section{RESULTS}

On examination of PDL cells under the microscope, it was clear that some cells were stained blue and others showed clear cytoplasm. Non-viable cells were stained blue, whereas viable cells appeared colorless; (Fig. 3A, B; arrow head and arrow respectively).

Platelet-rich fibrin (PRF) group demonstrated higher number and the percentage of PDL viable cells was (116.05/ 80.2\%); (Fig. 3A). The number of the PDL cells in Hank's balanced salt solution (HBSS) group was markedly lower than that in the experimental group (88.35/72.8\%); (Fig. 3B), table 1 . The difference was significant $(P$-value $<0.05)$.

\section{Periodontal ligament cells (Mean \pm SD)}

Groups

$\begin{array}{ccccc} & \text { Total } & \begin{array}{c}\text { Non } \\ \text { viable }\end{array} & \text { Viable } & \begin{array}{c}\% \text { of viable } \\ \text { cells }\end{array} \\ & & & & \\ \text { PRF } & 144.6 \pm & 28.55 \pm & 116.05 \pm & 80.27214763 \\ & \mathbf{1 5 . 1 2} & \mathbf{8 . 5 8} & \mathbf{1 4 . 2 6} & \\ & & & & \\ \text { HBSS } & 121.6 \pm & 33.25 \pm & 88.35 \pm & 72.82418826 \\ & \mathbf{1 1 . 5 9} & \mathbf{7 . 1 9} & \mathbf{7 . 8 0} & \end{array}$

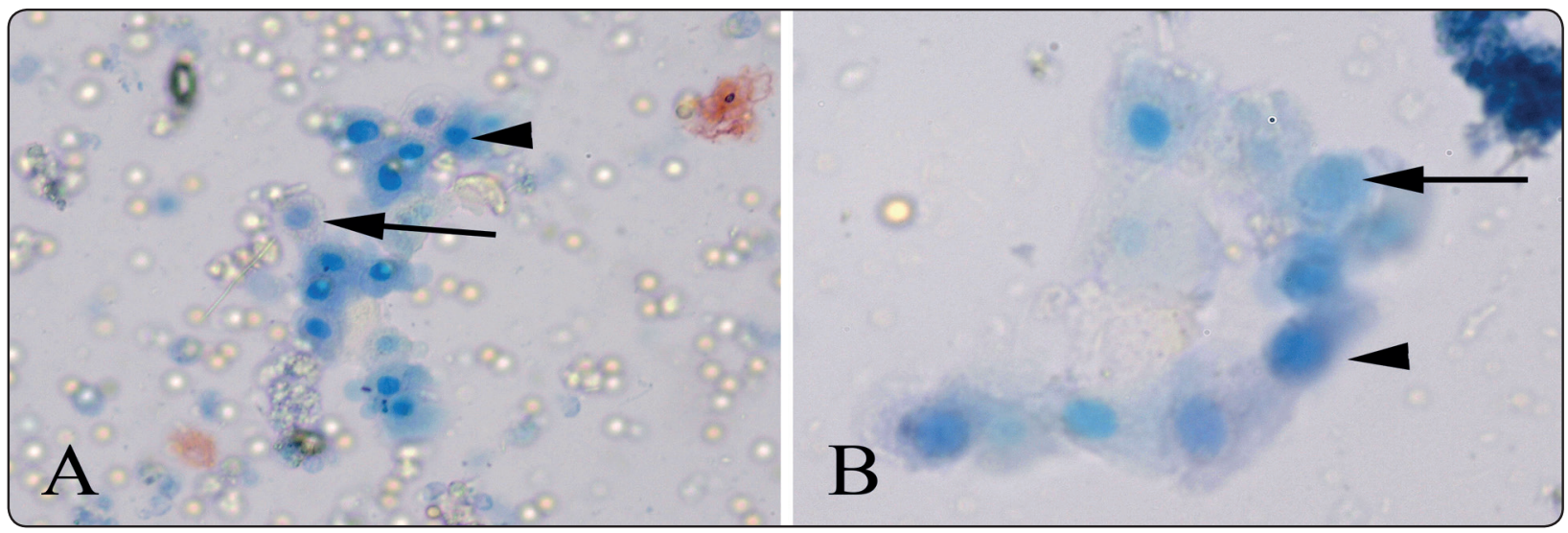

Fig. (3) Microscopic view of viable (arrow) and non-viable cells (arrow head) in PRF medium (A) and HBSS (B); (trypan blue; A, $\times-200$ and $B, x-400)$. 


\section{DISCUSSION}

Tooth avulsion is the condition in which a tooth has been removed from its socket as a result of trauma ${ }^{(25)}$. Clinical trials have revealed best prognosis and much higher reattachment success when avulsed teeth replanted within five minutes ${ }^{(26)}$.

In addition, periodontal ligament necrosis is the fate of many replanted teeth due to difficulties in replanting teeth soon after the accident ${ }^{(27)}$. Therefore, extra-oral dry time and storage media are essential factors affecting prognosis of avulsed teeth ${ }^{(28)}$.

Moreover, survival of replanted teeth is correlated directly with amount of viable periodontal membrane ${ }^{(29)}$.

Several transport media have been emerged to store avulsed teeth as immediate replantation is not possible such as HBSS, Viaspan, Eagle's medium, aloe vera and egg white. However, the disadvantages of most of these media are lack of availability and the high cost ${ }^{(30)}$. Therefore finding a storage medium that is available and cheap is the target of many workers in the dental field. Hence, the current study was undertaken to evaluate effectiveness of PRF as an autogenous transport medium for avulsed teeth using HBSS as a reference medium as the latter has great potential to maintain PDL cells in a viable state after avulsion ${ }^{(19)}$.

PRF is a fibrin membrane enriched with platelets and growth factors ${ }^{(31)}$. It is readily available, cheap and safe as it can be prepared with little effort from patients' own blood. A number of studies revealed proliferation and differentiation of osteoblasts and gingival fibroblasts by using $\operatorname{PRF}^{(32)}$.

In our study, the number of viable PDL cells in HBSS medium $(88.35 \pm 7.80,72.8 \%)$ is significantly lower than that in PRF medium (116.05 \pm 14.26 , $80.2 \%$ ). These findings could be attributed to the release of abundant amount of platelet-derived growth factors (PDGF) resulting in proliferation and survival of PDL cells ${ }^{(33)}$.
In addition, PRF releases growth factors shortly after preparation and its slow release continues over a period of time ${ }^{(34)}$. Moreover, Li et al demonstrated that PRF had significantly stronger effect on periodontal progenitor cell proliferation in vitro. These findings were attributed to different groups of cytokines trapped in PRF that are trapped in the fibrin mesh and released in a controlled manner ${ }^{(35)}$.

It was demonstrated that fibroblast function was affected by age, trauma and inflammation ${ }^{(30)}$. Therefore, sound teeth undergoing extraction for orthodontic treatment from young persons were selected in this study. In addition, PDL cells were shown to remain in non-compromised state up to 15 minutes of dry time ${ }^{(36)}$.

In the current study, the 25 minutes extra- oral dry time was undertaken to simulate avulsion injury that most avulsed teeth usually subjected. After 40-minute dry time, teeth were placed in PRF and HBSS for 30 minutes. This period was very important as PDL cells were most susceptible to damage ${ }^{(37)}$. So, keeping avulsed teeth in storage media may reduce damage.

Viable PDL cells were quantitated following treatment of root surfaces with dispase II protease that allows separation of PDL cells in vitro ${ }^{(38)}$. In addition, trypan blue easily differentiate viable from non viable cells as chromophore present on cell membrane doesn't take up trypan blue stain unless the membrane is damaged. Hence, all viable cells did not pick up the stain ${ }^{(39)}$.

Although HBSS medium has great potential to keep PDL cells in a viable state after avulsion, manipulation, cost and lack of availability make it less than ideal ${ }^{(19)}$. According to the present findings, PRF was shown to preserve PDL cells viability in avulsed teeth with an extra-dry time of 40 minutes in addition to its low cost, availability and ease of preparation. 
In this context, PRF demonstrated higher number of viable PDL cells. Accordingly, it could be a possible effective autogenous storage medium for avulsed teeth.

\section{REFERENCES}

1. Lee J, Divaris K. Hidden consequences of dental trauma: The social and psychological effects. Pediatr Dent 2009; 31: 96-101.

2. Martin MP, Pileggi R. A quantitative analysis of Propolis: a promising new storage media following avulsion. Dent Traumatol 2004; 20: 85-9.

3. Fountain SB, Camp JH. Traumatic injuries. In: Cohen S, Burns RC, eds. Pathways of the Pulp, 7th ed. St Louis: CV Mosby; 1998.

4. Tapias MA, Jiménez-Garcia R, Lamas F, Gil AA. Prevalence of traumatic crown fractures to permanent incisors in a childhood population: Móstoles, Spain. Dental Traumatol 2003; 19: 119-22.

5. Santos ME, Habecost AP, Gomes FV, Weber JB, de Oliveira MG. Parent and caretaker knowledge about avulsion of permanent teeth. Dent Traumatol 2009; 25: 203-8.

6. Andreasen JD. Traumatic injuries of the teeth. Copenhagen: Munksgaard; 1972.p.214.

7. Andreasen JO, Borum MK, Jacobsen HL, Andreasen FM. Replantation of 400 avulsed permanent incisors. Part 4. Factors related to periodontal ligament healing. Endod Dent Traumatol 1995; 11: 76-89.

8. Mori GG, Nunes DC, Castilho LR, Moraes IG, Poi WR. Propolis as storage media for avulsed teeth: microscopic and morphometric analysis in rats. Dent Traumatol 2010; 26: $80-5$.

9. Andreasen JO. Effect of extra-alveolar period and storage media upon periodontal and pulpal healing after replantation of mature permanent incisors in monkeys. Int J Oral Surg 1981; 10: 43-53.

10. Blomlof L, Lindskog S, Andersson L, Hedstrom K-G, Hammarstrom L. Storage of experimentally avulsed teeth in milk prior to replantation. J Dent Res 1983; 62: 912-6.

11. Blomlof L, Otteskog P. Viability of human periodontal ligament cells after storage in milk or saliva. Scand J Dent Res 1980; 88: 436-40.
12. Udoye C, Jafarzadeh H, Abbott P. Transport media for avulsed teeth: a review. Aust Endod J 2012; 38: 129-36.

13. Santos CL, Sonoda CK, Poi WR, Panzarini SR, Sundefeld ML, et al. Delayed replantation of rat teeth after use of reconstituted powdered milk as a storage medium. Dent Traumatol 2009; 25: 51-7.

14. Tsai CH, Shen SY, Zhao JH, Chang YC. Platelet-rich fibrin modulates cell proliferation of human periodontally related cells in vitro. J Dent Sci 2009; 4: 130-5.

15. Sigalas E, Regan J, Kramer P, Witherspoon D, Opperman L. Survival of human periodontal ligament cells in media proposed for transport of avulsed teeth. Dental Traumatol 2004; 20: 21-8.

16. Donaldson M, Kinirons M. Factors affecting the time of onset of resorption in avulsed and replanted incisor teeth in children. Dental Traumatol 2005; 21: 205-9.

17. Anitua E, Sánchez M, Orive G, Andía I. The potential impact of the preparation rich in growth factors (PRGF) in different medical fields. Biomaterials. 2007; 28: 4551-60.

18. Anitua E, Andia I, Ardanza B, Nurden P, Nurden AT. Autologous platelets as a source of proteins for healing and tissue regeneration. Thromb. Haemost. 2004; 91: 4-15.

19. de Souza BDM, Bortoluzzi EA, Teixeira CS, Felippe WT, Simões CMO, et al. Effect of HBSS storage time on human periodontal ligament fibroblast viability. Dent Traumatol 2010; 26: 481-3.

20. Goswami M, Chaitra TR, Chaudhary S, Manuja N, Sinha A. Strategies for periodontal ligament cell viability: an overview. J Conserv Dent 2011; 14: 215-20.

21. Dohan DM, Choukroun J, Diss A, Dohan SL, Dohan AJ, et al. Platelet-rich fibrin (PRF): a second-generation platelet concentrate. Part II: platelet-related biologic features. Oral Surg Oral Med Oral Pathol Oral Radiol Endod 2006; 101: e45-e50.

22. Trope M. Clinical management of the avulsed tooth: Present strategies and future directions. Dental Traumatol 2002; 18: $1-11$.

23. Johns DA, Shivashankar VY, Maroli RK, Vidyanath S. Novel management of avulsed tooth by pulpal and periodontal regeneration. J Endod 2013; 39: 1658-62.

24. Arunachalam MS, Pulikkotil SJ, Nath Sonia N. Platelet Rich Fibrin in Periodontal Regeneration. Open Dent J. 2016; 10: 174-81. 
25. Hiremath H, Kulkarni S, Sharma R, Hiremath V, Matiwata T. Use of platelet-rich fibrin as an autologous biologic rejuvenating media for avulsed teeth-an in vitro study. Dent Traumatol 2014; 39: 442-44

26. Dos Santa CL, Sanada CK, Poi WR, Purzarini SR, Sundefeld ML, et al. Delayed replantation of rat teeth after use of reconstituted powdered milk as a storage medium. Dent Traumatol 2009; 25: 51-7

27. Donaldson M, Kinirons MJ. Factors affecting the onset of resorption in avulsed and replanted incisor teeth in children. Dent Traumatol 2001; 17: 205-9

28. Chamorro MM, Regan JD, Opperman LA, Kramer PR. Effect of storage media on human periodontal ligament cell apoptosis. Dent Traumatol 2008; 24: 11-6

29. Hammer H. Replantation and implantation of teeth. Int Dent J 1955; 5: 439-57

30. Sharma M, Sharma S, Reddy YG, Agarwal V, Singh C, et al. Evaluation of periodontal ligament cell viability in three different storage media: An in vitro study. J Dent 2015; 12: 524-31

31. Choukroun J, Adda F, Scoeffer C, Verrelle A. PRF: an opportunity in perio-implantology. Implantodontie 2001; 42: 55-62

32. He L, Lin Y, Hu X, Zhang Y, Wu H. A comparative study of platelet-rich fibrin (PRF) and platelet-rich plasma (PRP) on the effect of proliferation and differentiation of rat osteoblasts in vitro. Oral Surg Oral Med, Oral Pathol Oral Radiol Endod 2009; 108: 707-13
33. Androe J, Gallini R, Betsholtz C. Role of platelet derived growth factors in physiology and medicine. Genes Dev 2008; 22: 1276-312

34. Pluemsakunthai W, Kuroda S, Shimokawa H, Kasugai S. A basic analysis of platelet-rich fibrin: distribution and release of platelet-derived growth factor-BB. Inflamm Regen 2013; 33: 164-72

35. Li Q, Pan S, Dangaria SJ, Gopinathan G, Kolokythas A, et al. Platelet-rich fibrin promotes periodontal regeneration and enhances alveolar bone augmentation. Biomed Res Int 2013; 01: 1-13

36. Pohl Y, Filippi A, Kiisschner H. Results after replantation of avulsed permanent teeth. II. Periodontal healing and the role of physiologic storage and antiresorptive-regenerative therapy. Dent Traumatol 2005; 21: 93-101

37. Pileggi R, Dumsha TC, Nor JE. Assessment of posttraumatic PDL cells viability by novel collagenase assay. Dent Traumatol 2002; 18: 186-9

38. Mahal NK, Singh N, Thomas AM, Kakkar N. Effect of three different storage media on survival of periodontal ligament cells using collagenase dispase assay. Int Endod J 2013; 46: 365-70

39. Sanghavi T, Shah N, Parekh V, Singbal K. Evaluation of efficacy of three different storage media, coconut water, propolis, and oral rehydration solution, in maintaining the viability of periodontal ligament cells. J Conserv Dent 2013; 16: 71-4 